\title{
INNOVATIVENESS OF CHOSEN POLISH TEXTILE-CLOTHING COMPANIES
}

\author{
Tomasz Czajkowski ${ }^{1}$, Maria Woźniak-Malczewska²
}

${ }^{1}$ Institute of Economy, Department of World Economy and European Integration, University of Lodz, ul. Rewolucji 1905r. 41/43, 90-214 Lodz, Poland, tel.+48 4263551 62, e-mail: tomasz.czajkowski@uni.lodz.pl

${ }^{2}$ Department of Innovations and Marketing, Chair of Management Systems and Innovation, Lodz University of Technology, ul. Wólczańska 215, 90-924 Łodz, Poland, tel./fax. +48 4263137 59, e-mail: maria.wozniak@p.lodz.pl

\section{Abstract:}

Innovation allows companies to obtain and maintain competitive advantage. Companies-even in the same sector of activities-often have various ways to reach this goal. The paper gives an insight to the most recent trends concerning the theory of innovations, presents four different innovative approaches, and illustrates them with the help of the selected Polish textile companies. Those companies are only a few selected from many that belong to this sector, which are innovative not only at the national, but also at the international level. The authors decided to present examples from this sector because there is a belief that it is one of the declining sectors of the Polish economy, while the presented examples clearly show that it includes companies that are innovative and can compete even on global markets.

\section{Keywords:}

Textile - clothing industry, competitive advantage, innovation, innovativeness, Poland

\section{Theoretical Introduction}

Innovation is driven by the skill to see connections, to notice opportunities, and to take advantage of them $[7,13,14,16$, $26,45,47]$. W. Baumol stated that almost "all of the economic growth that has occurred since the 18th century is ultimately attributable to innovation" [5]. It was true centuries ago and as noticed by managers and researchers, innovation becomes ever more important in today's increasingly global and knowledge-based economy [9, 11, 15, 20, 28, $30,41,43,45]$. Competitive advantage in most industries depends to a far larger extent today than in the pre-crises years, on the ability of companies to meet the changing market needs competently and rapidly. Innovation is about creating products, processes, and organizational changes that have a direct influence on company performance in terms of turnover increase or efficiency improvements [9, $17,25,39]$. This perception is now even recognized in emerging [1, 9] and developing [9] countries where it took longer to be acknowledged. Innovation is a term somewhat ambiguous and many different definitions were created by different authors. Definitions vary but they all emphasize new knowledge creation and the need for development [4, 13, 15, $17,25,27,39,47]$. J. A. Schumpeter [44] was among the first to lay out a clear concept of entrepreneurship and created the first definition of innovation in economic theory, the first use of the word "innovation" in its modern sense, of a useful and creative change. He distinguished technological inventions from the entrepreneur's innovations: "As long as they are not carried into practice, inventions are economically irrelevant" [43]. This perspective had been followed by many authors $[12,33,38,40]$. Literature classifies innovations according to various typologies $[14,16,28,37,39]$. They will not all be presented. Instead, the paper distinguishes the different type of innovations in chosen Polish textile producers from the point of view of the sources of their creation briefly introducing the different types.

For J. A. Schumpeter, the entrepreneur was the character who discovers untried ideas (though they can be present in a "general knowledge pool") and introduces them into economic life. He tried to show that entrepreneurs innovate not just by finding new ways of using inventions, but also by introducing new means of production, new products, and new forms of organization. He was also the first to observe that innovations are created by companies and thus need to be developed within a closed environment $[9,44]$. This innovation strategy has been the predominant view on innovations for years as it was seen as a perquisite to survive on the market. $\mathrm{H}$. W. Chesbrough followed the Schumpeterian perspective saying, "If you want something done right, you've got to do it yourself" [10]. K. Poznańska states that R\&D is viewed as one of the company activities leading to innovation by increasing the knowledge resources available, which, in turn, could serve new applications [41]. K. Pavitt notes that industrial R\&D was one of the major innovation sources in the 20th century [16]. Many companies still rely primarily on their own R\&D departments or employees to develop innovations, abandoning those projects that do not fit with their corporate strategy.

R\&D may be one of the determinants of innovation development but no longer the sole one [9]. E. Von Hippel [36, 53, 54] found that innovations do not only originate from the domain of the producers but also to a large extent from the users. For E. Von Hippel [53], "the innovator is defined as the individual or firm that first develops an innovation to a useful state, as proven by documented, useful output." For the author, the response time of those that may copy the innovation (effectively launch 
them on the market) is important in determining whether the innovation can be easily copied. An innovation is therefore a new tangible solution, which is useful. Since then, innovation management changed its perspective; value creation, which is the primary purpose of enterprises, is no longer solely attained by companies using their internal resources but also depends on distributed innovation capabilities outside the company $[9,28]$. According to J. Altkorn [3] the widest possibilities of enterprise development, regardless the sector, appear from observing the environment (both macro- and micro-). Innovations created this way are the most numerous and at the same time relatively low risk and rapidly implemented.

In this increasingly complex world, empowering customers and collaborating with a variety of strategic partners in a synergic relationship is essential as organizations find it otherwise difficult to survive in innovative environments [9, 32, 42, 47]. Information technology (IT) has played an important role in innovation and collaboration as it permitted all the participants to communicate more effectively [9]. Companies more often engage interactively with consumers, leading to innovation $[9,28]$. These empowered consumers show five key needs [9] namely (1) "customerization"-their need for uniqueness and personalization of products, services, and information, (2) community-the desire to interact within real or virtual groups, (3) convenient access - the need to interact with enterprises through multiple channels, (4) competitive value-the desire to meet one's needs at the best possible price, and (5) choicethe want to have the appropriate tools to make better-informed decisions.

Innovation always requires communication, not only with users and customers. Companies increasingly notice that they need to apply external knowledge to introduce innovative products successfully [28, 35, 52], even though innovation networks have existed since the beginning of industrialization [47]. An open innovation strategy implies the importance of interorganizational relations in order to allow the absorption of knowledge from a variety of external sources-universities, research institutions, appliers, and users [9]. Since the mid-1980s, the role of universities in commercializing research has grown immensely $[6,20,23]$. According to J. Tidd and J. Bessant, one of the emerging features of the 21st century innovation landscape is that it is a multientity activity [47]. Organizations of different sizes and with different goals work together in networks. Such a strategy drives further change but at the same time hinders the preservation of intellectual property within the company. Often, research institutions and universities develop technologies that companies do not find useful and inventions or new theories have not always been applied as innovations [19]. Nowadays, companies are inclined to outsource their R\&D to external entities. For the SMEs, this may be the only possibility to access new technologies or research facilities. For larger companies, such cooperation may allow to participate only in the research they feel is necessary. Such relations may be difficult to manage for both parties [16] as the expectations of researchers and managers may differ immensely when it comes to diffusion of knowledge about the findings and commercialization of the innovation. One of the main implications is to change the perspective from "a single enterprise to more of a systems view" [47]. Networking with external entities necessitates understanding relationships in order to build and establish different forms of collaboration $[2,51]$. Although the dynamics of such networks are different than operating in a single entity, the main innovation challenge remains the same-how to find the potential idea and develop it.

Own research, the company environment, customers, and more developed networks as sources of innovations-each presents a different company approach in developing new products or processes. The paper subsequently discusses the examples of each of these approaches in chosen Polish textile companies, which allows us to note that each of them is innovative even if their new product processes are differently inspired.

\section{Research Method}

The main purpose of the present article is to show that chosen T-C companies in Poland represent entities that are driven to innovate using the different innovation sources presented above. It proves that the Polish sector may be innovative if more companies would follow this approach. Practitioners must try to find a tactic that is most suitable for their specific situation instead of relying solely on previous experiences.

In order to achieve this purpose, empirical research has been conducted using a case study method for each of the enterprises [Matejun 2011, Yin 1984, Yin 2015]. The Internet was used for primary data collection (company websites, articles in journals). The information was further confirmed by direct contact (during meetings with entrepreneurs on different occasions or telephone contacts). Accepting the fact that "case findings are not readily generalizable" [Tsang 2015], no generalizations are made for the whole industry but an illustration of the theoretical approaches described above is done by showing a brief summary of each of the conducted cases.

\section{Innovativeness of Selected Polish T-C companies}

It was chosen to illustrate the approaches described above with cases-selected companies from the Polish textile clothing sector. Those companies are only a few selected from many that belong to this sector, which are innovative not only at the national, but also at the international level. The authors decided to present examples from this sector because there is a belief that it is one of the declining sectors of the Polish economy, while the presented examples clearly show that it includes companies that are innovative and can compete even on global markets.

\subsection{TZMO}

A good example of a company in the Polish T-C (textile and clothing) sector, which has its own R\&D department and spends a lot of resources for innovative activity, can be TZMO from Toruń. It is a global player operating, inter alia, on the market 
of medical textiles. TZMO employs more than 7000 workers in 17 countries, and whose capital group includes 53 companies. The products of TZMO are sold in 65 countries in Europe, Asia, America, and Australia. The R\&D of this company is done by its R\&D center, a subsidiary called Tricomed. It is an old Polish company (established in 1959), which became a part of the TZMO capital group in 2003, and in 2010 obtained a status of a R\&D center. It cooperates with universities and other scientific units in order to develop solutions from the field of medical engineering, biotechnology, and cosmetology, and also participates in several programmes of the European Union. The products belonging to the textile sector that are constantly produced and developed by TZMO are, inter alia, innovative wound dressings containing different additives that support healing of different types of wounds, specialist products for surgery (e.g., prosthesis, threads, nets, implantation materials, and products (under their own brand Matopat), female hygienic products (Bella brand), cotton hygienic products (e.g., ear buds or cosmetic pads (Bella Cotton brand)) and incontinence pads for elderly people with urological problems (Seni brand). Due to high spending on R\&D (counted in millions of Euro) and such wide range of developed products, TZMO can successfully keep up with the world biggest companies, like Procter \& Gamble or $3 \mathrm{M}$, even on the global market, sometimes being even more innovative than those corporations.

\subsection{Filter Service}

One of the very important issues in the modern world is personal protection. It is connected, inter alia, with an increase of the number of different hazardous works, and what follows with an increase of demand for products that ensure safety of people employed in industries connected with such works. Such demand generates the need for innovative products, which is an example of a pure market-driven innovation. In the Polish T-C sector, we have, for instance, a company called Filter Service, which constantly designs and develops new personal protective equipment (PPE), and therefore keeps up with the current trends on the market. This company was started in 1987, and in 1992 it gained its present name and legal form. From the beginning of its operation, it was connected with the market of PPE due to the production of filtration masks and half-masks, protective gloves, products for protection of eyes and ears, and others. The products of Filter Service are of the highest quality and fulfill its function in the best possible way, which was appreciated at many trade fairs in Poland and abroad (e.g., at the international $A+A$ trade fairs in Dusseldorf). In order to maintain the quality at the highest level, the company has introduced many production and management certifications and standards, inter alia, PN-EN ISO 9001, PN ISO 14001, and PN-N 18001. It also cooperates with universities and research units, and takes part in many EU projects. One of them was the project titled, "New generation filtration materials with the share of nano-fibres and modifiers," coordinated by the Centre of Advanced Technologies of Human-Friendly Textiles (PRO HUMANO TEX), which resulted in the introduction to the market of new filters BIO E 953 P3 R and BIO S 953 P3 R that can be joined with their half-masks and be used for the protection of the human breathing system against dust, smoke, and fluid aerosols, and also biological threats with the diameter larger than $0,3 \mu \mathrm{m}$. Another example of an innovative product that was introduced by Filter Service is a half-mask of SIMPLA series. They are of an anatomical shape, thanks to which there is no need for a nose clamp. This product has specially shaped protrusions in the places that are especially susceptible to leaking (nose surroundings), which allow for a very good fitting to the face of the user. They also do not have any metal elements. All of these factors make this product innovative not only in a Polish, but also international scale.

\subsection{Corin}

It is worth mentioning that there are also Polish enterprises from the clothing part of the textile-clothing sector that are innovative in the global scale. An example of such a company can be Corin, a producer of lingerie from Pabianice that is selling its products not only in Poland, but also many foreign countries (France, Belgium, Germany, the United States, Singapore, Iceland, etc.). This company received financial help from the $\mathrm{EU}$ and was able to start through cooperation with scientists from the Lodz University of Technology in order to develop an improved version of bras. They wanted to enhance both the comfort of wearing and also health properties of this part of a woman's clothing. Together, they conducted research (based, inter alia, on thermo-vision images of woman's breasts in traditional bras) and were able to make some alterations in the shape of the cups and increased the amount of available sizes of the bras that Corin produces. The bras that were developed during this project are being sold with a motto 'perfect bra'. It is not very modest, but certainly gives an idea about the new, improved bras that are safer for health, better fitted, and cause much less pressure for the body. This research was so innovative that it attracted attention from the world media. It is enough to mention that the TV channel Discovery Science featured a program about them, and it will be broadcast in the series 'How They Do It'.

\subsection{Knittex}

One of the most fundamental rules of modern marketing, developed by Kotler [29], says that a company should produce what it can sell, instead of selling what it can produce. The companies following this rule often have better results, because they listen to their consumers and therefore implement socalled user-driven innovations. In the modern world, it is much easier than before, as we have well developed information and communication technologies (ICT), to have an almost instantaneous communication between a consumer and a company. There can be found many examples of companies that utilize social media for contacts with their customers, but it was decided to show here an example of a small company Knittex. It is a small company producing hosiery. Even such a small company can have its Facebook profile and gather information from it about what its customers need and implement changes to its production and design. What is also important is that this company not only introduces innovations thanks to its Facebook profile and to opinions of users that are posted there, but also organizes many competitions, where consumers can win products of that company. 


\section{Conclusions}

Innovation-driven products may be obtained in numerous ways as the examples of TZMO, Filter Service, Corin, and Knittex show. Each of the approaches has its advantages and disadvantages, but allowed those companies to achieve a significant position in the Polish and international markets. Observing the market innovation leaders is an important lesson for those that want to enhance their offer being inspired not by the competition's products themselves (in order to avoid copying their rivals) but by the methods employed in the search of new product ideas. Both literature and practice provide a wide array of inspirations that may be considered and further adapted to the given company in order to achieve competitive advantage through innovations. Such approach may result in breakthrough inventions that can change the market and the given sector.

\section{References}

[1] Abrami, R. M., Kirby, W. C., McFarlan, F. W. (2014) Why China Can't Innovate. Harvard Business Review, 92(3), 107-111.

[2] Agarwal, R., Selen, W. (2013). The incremental and cumulative effects of dynamic capability building on service innovation in collaborative service organizations. Journal of Management \& Organization, 19, 521-543.

[3] Altkorn, J. (1994) Inspiracje innowacji rynkowych. Marketing i Rynek. 2

[4] Arruda, C., Rossi, A., Mendes, G., Ferreira, P. (2013) The Influence of External Search Strategies on the Innovative Performance of Brazilian Firms. RISUS, 4 (1), 43 - 59.

[5] Baumol, W. (2002) The Free-Market Innovation Machine: Analyzing the Growth Miracle of Capitalism. Princeton University Press (Princeton).

[6] Bower, J. (2003) Business model fashion and the academic spin out firm. R\&D Management, 33(2), 97-106.

[7] Brdulak, J. J. (2005) Zarządzanie wiedzą a proces innowacji produktu - Budowanie przewagi konkurencyjnej firmy. SGH (Warszawa).

[8] Brem, A.(Ed.), Viardot, É.(Ed.). (2013) Evolution of Innovation Management: Trends in an International Context. Palgrave Macmillan (Hampshire).

[9] Cetindamar, D., Phaal, R., Probert, D. (2009) Understanding technology management as a dynamic capability: A framework for technology management activities. Technovation. 29, 237-246.

[10] Chesbrough, H. W. (2003) Open Innovation: The New Imperative for Creating and Profiting from Technology. Harvard Business School Press (Boston).

[11] Damanpour, F., Walker, R. M., Avellaneda, C. N. (2009). Combinative effects of innovation types and organizational performance: A longitudinal study of service organizations. Journal of Management Studies, 46(4), 650-675.

[12] Dodgson, M., Gann, D. M., Salter, A. (2008) Management of Technological Innovation: Strategy and Practice. Oxford University Press (Oxford).

[13] Dolińska, M. (2010) Innowacje w gospodarce opartej na wiedzy. Polskie Wydawnictwo Ekonomiczne (Warszawa)

[14] Drucker, P. (1992) Innowacja i przedsiębiorczość. Praktyka i zasady. PWE (Warszawa).
[15] Duraj, J., Papiernik-Wojdera, M. (2010) Przedsiębiorczości innowacyjność. Difin (Warszawa).

[16] Fagerberg, J. (Ed.), Mowery, D. C. (Ed.), Nelson, R. R. (Ed.).(2005) The Oxford Handbook of Innovation. Oxford University Press (Oxford).

[17] Firszt, D. (2012) Uwarunkowania dyfuzji innowacji w polskiej gospodarce. CeDeWu.pl (Warszawa).

[18] Garlińska, G. (2005) Kierunek: innowacyjność. Nowe Życie Gospodarcze, 1 (385).

[19] Gillispie, C. C. (2004) Science and Polity in France: The Revolutionary and Napoleonic Years. Princeton University Press (Princeton).

[20] Grudzewski, W. M., Hejduk, I. K. (2008) Zarządzanie technologiami. Zaawansowanie technologie i wyzwania ich komercjalizacji. Difin (Warszwa).

[21] Grzybowska B., Juchniewicz M. (2005) Bariery działalności innowacyjnej polskich przedsiębiorstw. Ekonomika $i$ Organizacja Przedsiębiorstwa, 4 (663), 51-57.

[22] Hagedoorn J., Duysters, G. (2002) External sources of innovative capabilities: the preference for strategic alliances or mergers and acquisitions. Journal of Management Studies, 29, 167-188.

[23] Henderson, R., Jaffe, A., Trajtenberg, M. (1998) Universities as a source of commercial technology: a detailed analysis of university patenting 1965-1988. Review of Economics and Statistics, 119-127.

[24] Huang, H., Lai, M., Kao, M., Sung, C. (2014). A teamlearning framework for business model innovation in an emerging market. Journal of Management \& Organization, 20, 100-120.

[25] Janasz, W., Kozioł-Nadolna, K. (2011) Innowacje $w$ organizacji. Polskie Wydawnictwo Ekonomiczne (Warszawa).

[26] Jasiński, A.H. (2006) Innowacje i transfer techniki w procesie transformacji. Difin (Warszawa).

[27] Jörg, T., Akkaoui H. S. (2013) Architecting the Dynamics of Innovation. Proceedings of the International Conference on Intellectual Capital, Knowledge Management \& Organizational Learning. 222-230.

[28] Knosala, R., Boratyńska-Sala, A., Jurczyk-Bunkowska, M., Moczała, A. (2014) Zarządzanie innowacjami. Polskie Wydawnictwo Ekonomiczne (Warszawa).

[29] Kotler, P., Armstrong, G. (2012) Marketing. Wprowadzenie. Wolters Kluwer (Warszawa)

[30] Krawiec F.(2000) Zarzadzanie projektem innowacyjnym produktu i usługi. Difin (Warszawa).

[31] Léonard, J. (Ed.). (1998) Economies et Sociétés, Série "Débats" No. 3 - Innovation, Croissance et travail. Presses Universitaires de Grenoble (Grenoble).

[32] Lin, M. J., Tu, Y., Chen, D., Huang, Ch. (2013). Customer participation and new product development outcomes: The moderating role of product innovativeness. Journal of Management \& Organization, 19, 314-337.

[33] Mansfield, E. (2002) Economie managériale: Théorie et applications. De Boeck Université (Bruxelles, Paris).

[34] Matejun, M. (2011) Metoda studium przypadku w pracach badawczych młodych naukowców z zakresu nauk o zarządzaniu. Zeszyty Naukowe Uniwersytetu Szczecińskiego,, nr 666 - „Problemy Zarządzania, Finansów i Marketingu", 19, 203-213.

[35] Murray F., (2004) The Role of Academic Inventors in Entrepreneurial Firms: Sparing the Laboratory Life. Research Policy, 33 (4), 643-659.

[36] Newey, L., Verreynne, M. L. (2011). Multilevel absorptive capacity and interorganizational new product development: A process study. Journal of Management and Organization, 17(1), 39-55. 
[37] Ogawa, S., Pongtanalert, K. (2013) Exploring Characteristics and Motives of Consumer Innovators. Research Technology Management, 56(3), 41-48.

[38] Penc, J. (1999) Innowacje $i$ zmiany $w$ firmie. Placet (Warszawa).

[39] Pietrasiński, Z. (1971) Ogólne i psychologiczne zagadnienia innowacji. PWN (Warszawa).

[40] Pomykalski, A. (2001) Zarządzanie innowacjami. Wydawnictwo Naukowe PWN (Warszawa, Łódź)

[41] Porter, M. E. (1985) Competitive Advantage: Creating and Sustaining Superior Performance. Free Press (New York).

[42] Poznańska, K.(1998) Uwarunkowania innowacji w małych $i$ średnich przedsiębiorstwach. Dom Wydawniczy ABC (Warszawa).

[43] Prystron, J. (2012) Innowacje w procesie rozwoju gospodarczego: Istota i uwarunkowania. Difin (Warszawa).

[44] Scherer, F. M. (1986) Innovation and Growth Schumpeterian Perspectives. The MIT Press (Cambridge, Massachusetts).

[45] Schumpeter, J. A. (1960) Teoria rozwoju gospodarczego. PWN (Warszawa).

[46] Sosnowska, A., Łobejko, S., Kłopotek, A., Brdulak, J. , Rutkowska-Brdulak, A., Żbikowska, K. (2005) Jak wdrażać innowacje technologiczne $w$ firmie, PARP (Warszawa).

[47] Sosnowska, A., Łobejko, S. (2006) Małe $i$ średnie przedsiębiorstwa $w$ Polsce $w$ warunkach konkurencji: pozytywy i trudności w rozwoju. PARP (Warszawa).

[48] Tidd, J., Bessant, J. (2009) Managing Innovation: Integrating Technological, Market and Organizational Change (4th Edition). John Wiley \& Sons, Ltd (Chichester).

[49] Trocha, M. (2013). Jak powstał „Perfect Bra” czyli idealny biustonosz?, Retrived Sept. 21, 2014. Web site: $\quad$ http://www.p.lodz.pl/main, item11749, Jak powstal_Perfect_Bra_czyli_idealny_biust onosz_,wydarzenia_specjalne_index. $\bar{h} t m$
[50] Tsai, K. H. (2009). Collaborative networks and product innovation performance: Toward a contingency perspective. Research Policy, 38(5), 765-778.

[51] Tsang, E. W. K. (2014, Case studies and generalization in information systems research: A critical realist perspective. The Journal of Strategic Information Systems, 23 (2), 174-186.

[52] Utterback, J., Acee, H. (2005) Disruptive technologies an expanded view. International Journal of Innovation Management, 9 (1), 1-17.

[53] Van de Vrande, V. (2013) Balancing your technologysourcing portfolio: How sourcing mode diversity enhances innovative performance. Strategic Management Journal, 34, 610-621.

[54] Von der Heidt, T., Scott, S. (2011). More similar than different: A study of cooperative product innovation with multiple external stakeholders. Journal of Management and Organization, 17(1), 95-112.

[55] Von Hippel, E.(1988) The Sources of Innovation. Oxford University Press (New York, Oxford).

[56] Von Hippel, E.(2005) Democratizing Innovation. MIT Press (Cambridge).

[57] Yin, R. K. (1984) Case study research: Design and methods. Newbury Park, CA: Sage.

[58] Yin, R. K. (2015) Case Studies, ,International Encyclopaedia of the Social \& Behavioral Sciences (Second Edition)", 194-201.

[Internet sources:

[59] http://www.tzmo.pl/, Retrieved Aug 15, 2014

[60] http://matopat.pl/, Retrieved Aug 15, 2014

[61] http://www.filter.zgierz.pl, Retrieved Sept 21, 2014

[62] http://www.knittex.pl/, Retrieved Sept 21, 2014

[63] https://www.facebook.com/rajstopy.knittex, Retrieved Sept 21, 2014

[64] http://www.corin.eu/en/Home, Retrieved Sept 21, 2014 